Int. Archs Allergy appl. Immun. 1976;51:I-VII

\title{
Contents, Vol. 51, 1976
}

Vol. 51,1976

International Archives of Allergy andAppliedlmmunology

Founded 1950 by:

P. Kallós, Helsingborg

D. Harley, London

Fred W. Wittich,

W. Löffler, Zurich

Minneapolis, Minn.

Editors-in-Chief:

R. R. A. Coombs, Cambridge

P. Kallós, Helsingborg

G. B. West, Epsom

L. M. LlCHTENSTEIN,

F. Milgrom, Buffalo, N.Y.

Baltimore, Md.

Z. Trnka, Basel

Contributing

E. L. Becker,

L. Å. Hanson, Göteborg

A. Sehon, Winnipeg

Editors:

Farmington, Conn.

M. Hess, Bern

M. Simic, Belgrade

W. E. Brocklehurst,

Susan R. Hollán, Budapest

E. Sorkin, Davos Platz

Windlesham

T. Inderbitzin, Bern 
H. Storck, Zurich

A. Cerletti, Basel

H. Isliker, Lausanne

A. Szenberg, Melbourne

B. Diamant, Copenhagen

E. A. Kabat,

A. Szentivanyi, Tampa, Fla.

W. P. Faulk, Taplow,

New York, N.Y.

G. P. Talwar, New Delhi

Maidenhead, Berks.

R. Keller, Zurich

T. B. Tomasi, jr.,

M. Feldman, Rehovot

K. Ostrowsky, Warszaw

Buffalo, N.Y.

H. Fischer,

Ö. Ouchterlony, Göteborg

G. Torrigiani, Geneva

Freiburg-Zähringen

Z. Ovary, New York, NY.

J. L. Turk, London

R. van Furth, Leiden

R. Panzani, Marseille

E. R. Unanue, Boston, Mass.

P. G. H. Gell, Birmingham

P. Perlmann, Stockholm

G. A. Voisin, Paris

H. Gewurz, Chicago, Ill.

E. Pick, Tel-Aviv

B. H. Waksman,

I. Glazer, Tel Aviv

K. W. Pondman, Amsterdam

New Haven, Conn. 


\author{
R. A. Good, \\ M. Roitt, London \\ A. L. de Weck, Bern \\ New York, N.Y. \\ K. Rother, Heidelberg \\ G. Wick, Innsbruck \\ F. Hahn, Wittnau \\ D. S. Rowe, Lausanne \\ R. G. White, Glasgow

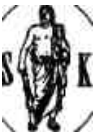

S. Karger · Basel · München · Paris · London · New York · Sydney

All rights, including that of translation into other languages, reserved.

Photomechanic reproduction (photocopy, microcopy) of this volume or parts thereof

without special permission of the publishers is prohibited.

(C) Copyright 1976 by S. Karger AG, Basel (Switzerland), Arnold-Böcklin-Strasse 25 Printed in

Switzerland by Buchdruckerei National-Zeitung AG, Basel

Contents

No.1

Notice to Authors

1

Meade, Ch. J. and Mertin, J.: The Mechanism of Immunoinhibition by Arachi-

donic and Linoleic Acid: Effects on the Lymphoid and Reticulo-Endothelial

Systems

2

Markussen, B.; Løwenstein, H., and Weeke, B.: Allergen Extract of Horse Hair

and Dandruff. Quantitative Immunoelectrophoretic Characterization of the

Antigens 25

Løwenstein, H.; Markussen, B., and Weeke, B.: Identification of Allergens in

Extract of Horse Hair and Dandruff by Means of Crossed Radioimmunoelectro-

phoresis 38

Løwenstein, H.; Markussen, B., and Weeke, B.: Isolation and Partial Charac

terization of Three Major Allergens of Horse Hair and Dandruff 48

Wilson, A. B. and Heller, E. D.: Passive Sensitization of Tissue Cells. V. The Detection of Chicken Antibodies Cytophilic for Basophils and Eosinophils ... 68

Mizumoto, T.: B and T Cells in the Lymphoid Tissues of Human Appendix .... 80

Nineham, L. J. and Hay, F. C.: A Solid-Phase Radioassay for the Detection of

Anti-Thyroglobulin Antibodies in Different Immunoglobulin Classes 94

Brochier, J.; Samarut, C; Gueho, J. P., and Revillard, J. P.: T-Dependence of

Human B Lymphocyte Proliferative Response to Mitogens 101

Ben-Efraim, S.; Ulmer, A.; Schmidt, M., and Diamantstein, T.: Differences

between Lymphoid Cell Populations of Guinea Pigs and Mice as Determined by

the Response to Mitogens in vitro 117

Ahlstedt, S.; Kristoffersson, A.; Svärd, P.-O.; Thor, L., and Örtengren, B.:

Ampicillin Polymers as Elicitors of Passive Cutaneous Anaphylaxis

Baer, H. and Hooton, M.: Effect of Season of Immunization on the Induction 
of Delayed Contact Sensitivity in the Guinea Pig 140

Erratum $\quad 144$

No. 2

Ahlstedt, S.; Kristoffersson, A.; Pettersson, E., and Svärd, P. O.: The Binding Properties of Rabbit Antibodies against Various Penicillins as Studied by Immunoprecipitation, Indirect Haemagglutination and Radiometric Immunoassay , 145

Rodell, A. K.; Ahlstedt, S.; Olsson, T. K., and Svärd, P. O.: Formation of Homocytotropic Antibodies with Penicilloyl Specificity in the Rabbit 156 IV

\section{Contents}

Lehman, D. H. and Wilson, C. B.: Role of Sensitized Cells in Antitubular Base ment Membrane Interstitial Nephritis 168

Leslie, G. A.; Stankus, R. P., and Martin, L. N.: Secretory Immunological System of Fowl. V. The Gallbladder: An Integral Part of the Secretory Immuno logical System of Fowl 175

Warrington, R. J.; Buehler, S. K., and Roberts, K. B.: Inflammation-Inducing Factors from Human Lymphocytes. Correlation with Polymorphonuclear

Leucocyte Migration Enhancement or Inhibition 186

Strånnegard, Ö. and Roupe, G.: Adjuvant Effect of Lysolecithin Analogues on the Development of Contact Sensitivity in Mice 198

Koga, T.; Kotani, S.; Narita, T., and Pearson, C. M.: Induction of Adjuvant Arthritis in the Rat by Various Bacterial Cell Walls and their Water-Soluble Components 206

Mori, S.; Kano, K., and Milgrom, F.: Heterophile Antigen Detectable by Infectious Mononucleosis Sera on Bone Marrow Cells 214 Ross, J. W.; Smith, H., and Spicer, B. A.: Increased Vascular Permeability during Passive Peritoneal Anaphylaxis in the Rat. The Effects of Disodium Cromoglycate and Nitroindanedione 226

Neveu, P. J. and Borduas, A. G.: Modulation of the Immune Response by Passive Antibodies. II. Effects of Passive Anti-Hapten and Anti-Carrier Antibodies on the Immune Response to a Sustained Antigenic Stimulation 238

Gershwin, M. E.; Glinski, W.; Bender, A. N.; Ringel, St. P.; Steinberg, A. D., and Engel, W. K.: Antibodies to Nucleic Acids in Myasthenia gravis 245 Lisak, R. P.; Zweiman, B., and Levinson, A. I.: Reactive and Nonreactive Lymphocytes in Experimental Allergic Encephalomyelitis. I. Possible Role of Macrophage-Lymphocyte Interactions 253

Kitamura, H.; Matsumoto, M., and Inai, S.: Necessity of the Divalent Cation in the Reaction between EACl-8hu and C9gp 265

Book Review 272

No. 3

Notice to Authors 273

Marshall, P. W.; Thomson, D. S., and Evans, D. P.: The Mechanism of Tachyphylaxis to ICI 74, 917 and Disodium Cromoglycate 274

Wicher, K.; Wicher, V., and Wang, M. C. C: Cellular and Humoral Immune Response of Guinea Pig Infected with Treponema pallidum 284 
Beranek, J. T.; DeCato, L., and Adler, F. L.: Binding of Morphine by Serum Globulins from Morphine-Treated Rabbits. I. Induction and Measurement of Binding 298

Ngan, J. and Kind, L. S.: Induction and Suppression of Reagins in the Neonatal Mouse 311

Martin, L. N.; Leslie, G. A., and Hindes, R.: Lymphocyte Surface IgD and IgM in Non-Human Primates 320

Contents

$\mathrm{V}$

Rabin, B. S.: Presence and Anatomic Location of Species and Organ-Specific Intestinal Antigens 330

Stux, S. V. and Ovary, Z.: Heterogeneity of Rabbit Homologous Skin Sensitizing Antibodies: IgE and a New Subclass IgG $\% 3338$

Koga, T.; Vande Sande, B.; Yeaton, R., and Pearson, C. M.: Reevaluation of Inguinal Lymph Node Injection for Production of Adjuvant Arthritis in the Rat 359

Butterworth, A. E.; Coombs, R. R. A.; Gurner, B. W., and Wilson, A. B.:

Receptors for Antibody-Opsonic Adherence on the Eosinophils of Guinea Pigs 368

Romagnani, S.; Amadori, A.; Biti, G.; Bellesi, G., and Ricci, M.: In vitro Lym

phocyte Response to Phytomitogens in Untreated and Treated Patients with

Hodgkin's Disease 378

Short Communications Bassi, L.; Di Berardino, L., and Silvestri, L. G.: IgE Antibodies in Patients

Allergic to Rifampicin $\quad 390$

Koga, T.; Kato, K.; Kotani, S.; Tanaka, A., and Pearson, C. M.: Effect of

Degradation of the Arabinogalactan Portion of a Water-Soluble Component

from M. tuberculosis Wax D on Polyarthritis Induction in the Rat 395

No. 4

Notice to Authors 401

Beranek, J. T.; DeCato, L., and Adler, F. L.: Binding of Morphine by Serum

Globulins from Morphine-Treated Rabbits. II. Antibody Nature of the Binding

Globulins $\quad 402$

Ovary, Z.; Kaplan, B., and Kojima, S.: Characteristics of Guinea Pig IgE 416

Dineen, J. K. and Kelly, J. D.: Levels of Prostaglandins in the Small Intestine of

Rats during Primary and Secondary Infection with Nippostrongylus Brasiliensis 429 Nielsen, K.; Holmes, W.; Wilkie, B., and Tizard, L: Bovin Reaginic Antibody.

I. Rat Mast Cell Degranulation by Bovine Allergic Serum 441

Kohashi, O.; Pearson, CM.; Shimono, T., and Kotani, S.: Preparation of

Various Fractions from Mycobacterium smegmatis, Their Arthritogenícity and

Their Preventive Effect on Adjuvant Disease 451

Kohashi, O. and Pearson, C. M.: Arthritogenicity of Mycobacterium smegmatis

Subfractions, Related to Different Oil Vehicle and Different Composition.... 462 Berg, T. and

Johansson, S. G. O.: In vitro Diagnosis of Atopic Allergy. V. The

Value of Repeated Testing Using Several Batches of the Allergen Extract .... 471 Dumont, F. and

Robert, F.: Dose-Related Effect of Hydrocortisone Treatment

on the Electrokinetic Properties and Mitogen Responsiveness of Mouse Thymo-

cytes 482 
FÉsüs, L.; Csaba, B., and Muszbek, L.: Activation and Consumption of Hageman Factor in the Anaphylactic Shock of the Rat 496

Chand, N.; Carlson, H. C, and Eyre, P.: Passive Cutaneous Anaphylaxis in the Domestic Fowl 508

VI

Contents

Short Communication

Budzko, D. B. and Negroni, R.: Depletion of Complement in vivo and in vitro by Extracts of Aspergillus fumigatus 518

Book Reviews 525

No. 5

Markham, R. J. F. and Wilkie, B. N.: Influence of Detergent on Aerosol Allergic Sensitization with Enzymes of Bacillus subtilis 529

McIntosh, J.; Hansen, P.; Ziegler, J., and Penny, R.: Defective Immune and Phagocytic Functions in Uraemia and Renal Transplantation 544

Holt, P. G.; Fimmel, P. J.; Bartholomaeus, W. N.; Roberts, L. M.; Tandon, M. K., and Keast, D.: Dissociation of Correlates of Cellular Immunity in Man: Functional Heterogeneity within the Antigen-Reactive Cell Population? 560 Jedrzejczak, W. W.: Phytohaemagglutinin (PHA) Skin Test in Predicting Progno sis in Cancer Patients 574

Koga, T.; Tanaka, A., and Pearson, CM.: Synergism of Immunogenic and Adjuvant-Active Components of Mycobacterial Wax D in the Induction of Adjuvant Arthritis 583

Bruley-Rosset, M.; Florentin, I.; Khalil, A. M., and Mathé, G.: Nonspecific Macrophage Activation by Systemic Adjuvants. Evaluation by Lysosomal Enzyme and in vitro Tumoricidal Activities 594

Krüger, P. G.: The Histamine Release Process and Concomitant Structural Changes in Rat Peritoneal Mast Cells. In vitro Study on Effects of Compound 48/80 and the Dependence of the Process on Cell Preparation, Temperature and Calcium $\quad 608$

Flemström, G.; Marsden, N. V. B., and Richter, W.: Passive Cutaneous Anaphylaxis in Guinea Pigs Elicited by Gastric Absorption of Dextran Induced by Acetylsalicylic Acid 627 Short Communication Dhar, H. L.; Hanahoe, T. H. P., and West, G. B.: Sugar Polymers in Rats and

Man 637

No. 6

Krell, R. D. and Chakrin, L. W.: An in vitro Model of Canine Immediate-Type Hypersensitivity Reactions 641

Socha,W. W.; Wiener, A. S.; Moor-Jankowski, J.; Scheffrahn, W., and

Wolfson, S. K. jr.: Spontaneously Occurring Agglutinins in Primate Sera 656

Tak Yan Yu, D.: Effect of Hydrocortisone on Response of Human Lymphocytes to Galactose Oxidase Stimulation 671

Contents

VII 
Sharbaugh, R. J.; Ainsworth, S. K., and Fitts, C. T.: Lack of Effect of Azathioprine on Phytohemagglutinin-Induced Lymphocyte Transformation and Established Delayed Cutaneous Hypersensitivity 681

Justus, D. E. and Adams, D. A.: Evaluation of Tobacco Hypersensitivity Responses in the Mouse. A Potential Animal Model for Critical Study of Tobacco Allergy 687

Callahan, H. J.: Preparation of an Infectious Mononucleosis Receptor from Sheep Erythrocyte Stroma 696

Namba, Y. and Waksman, B. H.: Analysis of T-Cell-Specific Functions in Continous Lymphocytic Cell Lines. II. A T-Cell-Line which Forms Rosettes with Normal Thymocytes of the Same Species 709

Fauci, A. S.; Balow, J. E., and Pratt, K. R.: Cytotoxic Effector Capacity of Bone Marrow Mononuclear Cells 721

Sengar, D. P. S.; Rashid, A., and Harris, J. E.: Lymphocyte Transformation in Human Plasma without Addition of Synthetic Medium. A Study of Immune Function in Patients with Chronic Uraemia or Diabetes mellitus 732 Zschiesche, W.; Fahlbusch, B., and Gutsche, W.: Presence and Characterization of Lymphokines in Mouse Ascites Tumor Fluids 742

Short Communications Pang, G. T. M.; Wiggins, P. M., and Wilson, J. D.: Nature of the Union between

Sheep Red Blood Cells and T Lymphocytes 751

Elwing, H.; Nilson, L.-Å., and Ouchterlony, Ö.: Visualization Principles in

Thin-Layer Immunoassays (TIA) on Plastic Surfaces 757

Book Reviews $\quad 763$

Varia $\quad 767$

Errata $\quad 769$

Author Index $\quad 770$ 